\title{
Epipodophyllotoxin Analog GL331
}

National Cancer Institute

\section{Source}

National Cancer Institute. Epipodophyllotoxin Analog GL331. NCI Thesaurus. Code C1866.

An epipodophyllotoxin analogue possessing antineoplastic properties. GL331 binds to and inhibits topoisomerase II, resulting in the accumulation of single- or double-strand DNA breaks, the inhibition of DNA replication and transcription, and apoptotic cell death. ( $\mathrm{NCl})$ 